\title{
Upaya Pencegahan HiV-AIDS Melalui Penyuluhan Kesehatan Untuk Meningkatkan Pengetahuan Siswa SMK Farmasi Kabupaten Sumbawa
}

\author{
Nur Arifatus Sholihah', Asri Reni Handayani², Galuh Permatasari ${ }^{3}$ \\ ${ }^{1}$ Prodi S1 Kesehatan Masyarakat Stikes Griya Husada Sumbawa \\ 2 Prodi S1 Keperawatan STIKES Griya Husada Sumbawa \\ ${ }^{3}$ Prodi DIII Kebidanan STIKES Griya Husada Sumbawa
}

\section{A B S T R A C T}

HIV-AIDS is a sexually transmitted disease whose appearance is like an iceberg phenomenon, namely the number of reported sufferers is much smaller than the actual number of sufferers. The spread of HIV-AIDS is strongly influenced by factors of education, knowledge, attitudes and behavior. The provision of information is expected to increase knowledge and can be done by providing sosializaton to the community, group or individual. This study aims to prove that HIV-AIDS counseling has an effect on the level of knowledge about HIV-AIDS. The design of this study was a pre and post test group, involving 30 students of Pharmacy Vocational School in Sumbawa Regency, which were selected using simple random sampling technique. The mean level of knowledge of students before counseling was 12.03 and after counseling was 17.97. The $p$-value of the t-test is 0.0001 , thus it is interpreted that counseling has an effect on the level of knowledge of students about HIV/AIDS at the Pharmacy Vocational School of Sumbawa Regency. Thus, it is important to increase knowledge and understanding of how to prevent and treat HIV Aids, especially among adolescents through sosialization about HIV-AIDS.

Keywords : blood lead level; breastfeeding mothers; erythrocyte

\begin{tabular}{|c|c|c|}
\hline \multicolumn{3}{|c|}{ ARTICLE INFO } \\
\hline \multicolumn{3}{|c|}{ Article history } \\
\hline Received & : & 5 January 2022 \\
\hline Revised & : & 27 January 2022 \\
\hline Accepted & : & 30 January 2022 \\
\hline
\end{tabular}

DOI:

DOI: 10.31983/micajo.v3i1.8180

\begin{tabular}{lll}
\multicolumn{2}{l}{ CORRESPONDING AUTHOR } \\
Name & $:$ & Nur Arifatus Sholihah \\
Email & $:$ & arifatus93@gmail.com \\
Telp & $:$ & 082134526141 \\
Address & $:$ & Prodi S1 Kesehatan \\
& & Masyarakat Stikes \\
& & Griya Husada \\
& Sumbawa
\end{tabular}

ORIGINAL RESEARCH

\section{Pendahuluan}

Human Immunodeficiency Virus (HIV) dan Acquired Immune Deficiency Syndrome (AIDS) merupakan penyakit menular seksual yang keberadaannya seperti fenomena gunung es dimana jumlah penderita yang terlaporkan lebih sedikit dibandingkan jumlah penderita yang sebenarnya. Jumlah penderita sebenarnya lebih tinggi. Hal ini menimbulkan masalah kesehatan. (Nugroho, 2010). Data dari World Health Organization (WHO) menyebutkan 0,8\% masyarakat dunia usia 15 - 49 tahun hidup dengan HIV. (WHO, 2014) Indonesia merupakan salah satu negara yang mengalami peningkatan kasus yang cukup tinggi. Secara kumulatif di Indonesia, dari tahun 1987 hingga September 2014 jumlah kasus HIV adalah 150.296 orang dan AIDS sebanyak 55.779 orang. Sebanyak 50,7\% kasus AIDS dari tahun 1987 hingga september 2014, terjadi pada remaja yang berusia 15-29 tahun (Kementerian Kesehatan Republik Indonesia, 2014). Faktor resiko HIV-AIDS tertinggi didominasi heteroseksual, pengguna NAPZA suntik dan diikuti kelompok lain- lain. (Kemenkes, 2014)

Usia remaja mempunyai sifat ingin tahu yang sangat besar sehingga menyebabkan mereka mencoba segala sesuatu yang menurut mereka menarik. (Fauzan \& A.Sirait, 2002) Jika tidak tersedia informasi yang tepat dan relevan tentang penyakit HIV-AIDS, sikap ingin tahu 
mereka bisa menyebabkan mereka masuk ke dalam resiko penularan HIV-AIDS. Selain itu, masalah HIV-AIDS pada remaja selain berdampak secara fisik, juga dapat berpengaruh terhadap kesehatan mental, emosi dan keadaan ekonomi dan kesejahteraan social jangka panjang. Hal tersebut tidak hanya berpengaruh terhadap remaja itu sendiri, tetapi juga terhadap keluarga, masyarakat dan bangsa pada akhirnya. (UNFPA, 2005)

Salah satu upaya dalam pencegahan dan HIV-AIDS yaitu dengan pemberian pengetahuan pada umur 15-24 tahun (Pusat Promosi Kesehatan RI, 2013). Cara yang digunakan antara lain penyuluhan, pendidikan kesehatan masyarakat, individu dan kelompok melalui media informasi dan teknologi sehingga pengetahuan tentang kesehatan meningkat dan mempunyai sikap positif terhadap kesehatan (Sukidjo Notoatmodjo, 2012)

WHO menyatakan bahwa remaja di negara - negara berkembang sangat membutuhkan pendidikan kesehatan. Remaja pada usia sekolah mempunyai resiko melakukan hubungan seksual diluar nikah. Oleh karena itu masa yang paling sesuai dilakukan penyuluhan adalah masa sekolah menengah atas (SMA) (World Health Organization, 2011) Pengetahuan remaja tentang HIV-AIDS dipengaruhi oleh pendidikan, pengalaman pribadi, kebudayaan, media masa. Remaja yang lebih tahu tentang kesehatan reproduksi akan menghindari melakukan seks bebas dan pengunaan napza menghindari pemakaian alat suntik bergantian, oleh sebab itu peneliti tertarik untuk membuat penelitian tentang pengaruh penyuluhan terhadap pengetahuan HIV dan AIDS pada siswa siswi SMA. Karena cara bersikap terhadap suatu objek ditentukan dari pengetahuan tentang objek tersebut dan penting bagi kita untuk membuat perencanaan pencegahan HIV- AIDS.

Penelitian ini merupakan salah satu upaya pencegahan dan penanggulangan HIV-AIDS di Sekolah Sekolah Menengah Kejuruan (SMK) Farmasi Kabupaten Sumbawa. Hasil observasi dan wawancara beberapa siswa serta beberapa guru menunjukkan bahwa belum pernah diadakannya sosialisasi terkait dengan pengetahuan tentang Penyakit HIV-AIDS. Berdasarkan hal tersebut, penulis tertarik untuk melakukan penelitian yang melibatkan mahasiswa terkait HIV AIDS.

\section{Metode}

Lokasi pengambilan data dilaksanakan di SMK Farmasi Kabupaten Sumbawa pada bulan Desember 2021. Penelitian ini menggunakan desain eksperimen Quasi dengan rancangan Pre and Post Test Group Design.. Populasi pada penelitian ini adalah seluruh siswa-siswi SMK Farmasi tahun 2021. Sampel dihitung menurut Sopiyudin Dahlan, berdasarkan rumus komparatif numerik berpasangan yaitu:

$$
\mathrm{n} 1=\mathrm{n} 2=\left[\frac{(\mathrm{Z} \alpha+\mathrm{Z} \beta) \mathrm{S}}{\mathrm{X}_{1}-\mathrm{X}_{2}}\right]^{2}
$$

Hasil dari rumus tersebut diperoleh besar sampel 30, yang diambil dengan cara simple random sampling. Variabel bebas dalam penelitian ini adalah pemberian penyuluhan, sedangkan variabel terikat adalah tingkat pengetahuan. Tingkat pengetahuan diukur dengan menggunakan kuesioner yang terdiri dari 30 pertanyaan yang sudah valid dan reliabel. Pengambilan data melalui 3 (tiga) tahap, tahap I: responden dikumpulkan di dalam kelas kemudian diminta mengisi kuesioner yang telah disiapkan (data pengetahuan pre test); tahap 2: responden diberi penyuluhan tentang HIV-AIDS melalui metode ceramah dan diskusi menggunakan media LCD yang dilakukan satu kali dengan durasi kurang lebih 60 menit (intervensi); tahap 3: responden diminta mengisi kuesioner pengetahuan (data post test). Data yang diperoleh merupakan data skor pengetahuan yang mempunyai skala rasio, sehingga 
yang pertama dilakukan adalah uji normalitas untuk menentukan uji statistik yang digunakan apakah parametrik atau non parametrik. Hasil uji normalitas dinyatakan bahwa distribusi data normal $(p>0,05)$, untuk mengetahui apakah skor pengetahuan sebelum dan sesudah penyuluhan ada perbedaan yang bermakna maka perlu dilakukan analisis dengan uji uji $t$ berpasangan (paired t test), dimana keputusan menerima atau menolak hipotesis berdasarkan $\alpha=5 \%$

\section{Hasil dan Pembahasan}

Pada tabel 1 menunjukkan bahwa jenis kelamin peserta penelitian adalah laki-laki (60\%), $40 \%$ berumur 17 tahun dan $23,3 \%$ responden mendapatkan sumber informasi tentang HIV-AIDS melalui orang tua dan media elektronik.

Responden merupakan dalam kategori umur remaja. Terdapat kaitan yang erat antara pendidikan dengan kondisi HIV-AIDS. HIV dan AIDS memberikan dampak negatif terhadap akses dan kualitas pendidikan yang mungkin didapatkan oleh seorang anak (Sutrisna, 2009) Edukasi tentang HIV AIDS pada anak dan remaja sangat penting untuk diberikan. Tindakan ini dilakukan sebagai cara mencegah terjadinya HIV dan AIDS sejak dini, yang nantinya bisa anak terapkan hingga dewasa kelak. Sayangnya, masih banyak yang menganggap bahwa edukasi terkait HIV pada remaja adalah sebuah hal yang tabu untuk dibicarakan. Padahal, dengan memberikan edukasi pada remaja dengan cara yang tepat, ini bisa menjadi langkah tepat untuk memutus rantai penyebaran virus HIV/AIDS di lingkungan tempatnya tinggal dan bergaul.

Tabel 1. Karakteristik Responden

\begin{tabular}{lcc}
\hline \multicolumn{1}{c}{ Karakteristik Siswa } & Frekuensi & Presentase \\
\hline Jenis Kelamin & 12 & 40 \\
Laki-Laki & 18 & 60 \\
Perempuan & & 20 \\
Umur Responden & 6 & 26,7 \\
15 & 8 & 40 \\
16 & 12 & 13,3 \\
17 & 4 & 16,7 \\
18 & & 23,3 \\
Sumber Informasi & 5 & 20 \\
Guru & 7 & 10 \\
Orang tua/ kerabat & 6 & 6,7 \\
Internet & 3 & 23,3 \\
Teman & 2 & \\
Media Cetak & 7 & \\
Media Elektronik & & \\
\hline
\end{tabular}

Penggunaan media juga sangat mempengaruhi terkait dengan jumlah paparan informasi yang didapatkan oleh remaja dalam self education tentang HIV AIDS. Menurut (Solehati et al., 2019) Media sosial yang sering mereka gunakan seperti text messaging, Internet, mobile applications, dan social networking memungkinkan pengguna mendapatkan informasi yang penting tentang topik-topik kesehatan. Pengguna media tersebut dapat menjadi komponen kunci pada intervensi kesehatan dan dapat memfasilitasi perilaku berisiko.

Hasil kuesioner pretest dan posttest dilakukan uji statistika dengan menggunakan uji paired sample t-test dengan hasil sebagai berikut. 
Tabel 2. Rerata Skor Pengetahuan sebelum dan sesudah penyuluhan

\begin{tabular}{ccc}
\hline $\begin{array}{c}\text { Kategori } \\
\text { Pengetahuan }\end{array}$ & Rerata Skor Pengetahuan & p- Value \\
\hline Sebelum Penyuluhan & 12,03 & $<0,001$ \\
Sesudah penyuluhan & 17,97 & $<$ \\
\hline
\end{tabular}

Tabel 2 menunjukkan bahwa hasil rerata skor pengetahuan siswa-siswi sebelum dilakukan penyuluhan 12,03 dan sesudah penyuluhan rerata skor pengetahuan menjadi 17,9. Hal ini menunjukkan ada kenaikan skor pengetahuan. Hasil analisis dengan t- paired diperoleh $p$ value $=0,000(p=<0,05)$, artinya bahwa penyuluhan meningkatkan pengetahuan tentang HIVAIDS siswa siswi SMK Farmasi Kabupaten Sumbawa. Pengetahuan yang didapatkan dari akses informasi harus tepat dan cepat agar membantu siwa-siswi dalam meningkatkan pengetahuan dan pemahaman tentang bagaimana cara mencegah dan menanggulangi HIV AIDS terutama pada kalangan remaja.

\section{Simpulan}

Penyuluhan kesehatan ini dapat membantu siwa-siswi untuk meningkatkan pengetahuan dan pemahaman tentang bagaimana cara mencegah dan menanggulangi HIV AIDS terutama pada kalangan remaja

\section{Ucapan Terimakasih}

Ucapan Terimakasih ini disampaikan kepada seluruh pihak terkait dengan kegiatan penelitian masyarakat, baik kepada Kepala SMK Farmasi beserta jajarannya dan kepada siswa-siswi Sekolah SMK Farmasi Kabupaten Sumbawa yang sudah bersedia menjadi responden, kepada mahasiswa yang terlibat, serta tak lupa kepada Suami tercinta Mas Dian Bagus Candra Kusuma, S.Kom yang senantiasa ikut serta mendampingi penulis dalam setiap kegiatan.

\section{Daftar Pustaka}

Fauzan, F., \& A.Sirait, B. (2002). Pendidikan Seks Bagi Remaja. Rineka Cipta.

Kemenkes, R. (2014). Situasi dan Analisis HIV AIDS.

Nugroho. (2010). Buku Ajar Obstetri. Nuha Medika.

Solehati, T., Rahmat, A., \& Kosasih, C. E. (2019). Relation of Media on Adolescents'

Reproductive Health Attitude and Behaviour. Jurnal Penelitian Komunikasi Dan Opini Publik, 23(1). https://doi.org/10.33299/jpkop.23.1.1768

Sukidjo Notoatmodjo. (2012). Metode Penelitian Kesehatan Edisi Revisi. PT. Rineka Cipta.

Sutrisna, A. (2009). Dampak HIV Pada Pendidikan Anak di Indonesia. Child Poverty and Sosial Protection Conference, 1-24.

UNFPA. (2005). The 2005 World Summit.

World Health Organization. (2011). Guidelines on Reproductive Health. 